\title{
Implicit Amenity Prices and the Location of Retirees in England and Wales
}

\author{
J. Lee ${ }^{\mathrm{a}}$ and G. Stewart ${ }^{\mathrm{b}}$
}

\begin{abstract}
General equilibrium models in which compensation for local amenities occurs in both housing and labour markets have been widely used to generate implicit amenity prices and regional quality of life indices. An implication and prospective test of such models is that individuals who are outside the labour market have an incentive to locate in regions where amenities are capitalised into wages. In this paper we construct a measure of the extent of amenity capitalisation into wages for each county in England and Wales. We then test the multimarket amenity model by applying this measure to county-level data on the location of retirees. Our results provide strong support for the model.
\end{abstract}

\footnotetext{
${ }^{a}$ Isle of Man International Business School, Douglas, IM2 1QB. j.lee@ibs.ac.im

${ }^{\mathrm{b}}$ Corresponding author. Economics Division, University of Southampton, Southampton, SO17 1BJ. gs@soton.ac.uk
} 


\section{Introduction}

In a seminal contribution to the literature on the value of amenities, Roback (1982) demonstrated how, in a general equilibrium setting, differences in amenities across locations are capitalised in both land and labour markets. A central assumption of the model is that workers and firms are mobile so that in equilibrium both utility and production costs are equalised across locations. Thus for workers, locations with good amenities will be characterised by high land prices and/or low wages. The framework has been applied not only to amenity pricing but also to generate regional quality of life indices (see, for example, Blomquist, Berger and Hoehn, 1988, Gyourko and Tracy, 1991, Srinivasan and Stewart, 2004, and Berger, Blomquist and Peter, 2008).

One interesting prediction, and prospective test of the model, concerns the location of individuals that are not in the labour force. As pointed out by Graves and Waldman (1991), such individuals will have an incentive to locate in regions where compensation for amenities occurs mainly in the labour rather than land market. Graves and Waldman test the prediction using US data on the migration of individuals aged 65 and over, and find support for the model. In this paper we apply the model to the location decisions of retirees in England and Wales. Drawing on estimates of amenity prices in Srinivasan and Stewart (2004), we examine variations across counties in the proportion of the population that are retired and migration flows of individuals aged 60 and over. Our findings offer additional support for the model and the associated quality of life indices.

\section{II.Model}

Following Blomquist, Berger and Hoehn (1988) and Gyourko and Tracy (1991), we consider a variation of Roback's model in which working households are endowed with one unit of labour and gain utility from a composite good, housing services and local amenities. In equilibrium utility is the same in all locations and can be expressed in terms of the indirect utility function:

$$
v\left(w_{k}, h_{k} ; a_{k}\right)=v^{0}
$$

where, the subscript $k$ refers to regions, $w_{k}$ denotes the wage rate, $h_{k}$ the price of housing, and $a_{k}$ a vector of amenities.

Firms produce the composite good using labour and land with a constant returns to scale production function. The product is sold at a price normalised to unity and, in equilibrium, unit costs are equal in all locations:

$$
c\left(w_{k}, r_{k} ; a_{k}\right)=1
$$

where $r_{k}$ denotes the price of land.

Housing is similarly produced under constant returns to scale, with unit costs equated to the price, $h_{k}$ : 


$$
h\left(w_{k}, r_{k} ; a_{k}\right)=h_{k}
$$

Equations (1), (2) and (3) determine the wage, price of land and price of housing associated with the level of amenities in a particular region. Totally differentiating (1) and using Roy's identity, we obtain the implicit price of an amenity:

$$
P_{k} \equiv \frac{v_{a}}{v_{w}}=\theta_{k} \frac{d h_{k}}{d a_{k}}-\frac{d w_{k}}{d a_{k}}
$$

where $\theta_{k}$ denotes the quantity of housing.

Estimates of the right hand side terms of (4) can be obtained from cross-section hedonic house price and wage regressions and thus used to generate implicit prices for each amenity, $i$. Summing over the amenities in region $k$ then yields its quality of life index value:

$$
Q O L_{k}=\sum_{i} P_{i} a_{i k}
$$

where $a_{i k}$ denotes the amount of amenity $i$ in region $k$.

Consider now the situation facing a household that is not in the labour force and happens to live in a hypothetical location with zero levels of each amenity. If this household were to relocate to location $k$, it would experience a gain in utility (in money terms) of

$$
-\sum_{i} a_{i k} \frac{d w}{d a_{i}}
$$

This prediction forms the basis of our test of the model.

\section{Data and results}

Data on the location of retirees, migration flows and amenities were collected for each of the 55 counties in England and Wales. The retirement location variable is the proportion of the population of pension age or over ( 60 for women and 65 for men) in each county. This was obtained from Regional Trends. The migration data is based on National Health Service records. When a patient transfers to a new National Health Service doctor in a different Family Health Service Authority, the details are passed to the National Health Service Central Register. This information can be used to generate proxies for migration flows between counties which are published, by broad age groups, in Key Population and Vital Statistics. The data on amenities come from a variety of sources as detailed in the Appendix. The set of amenities and the data period (1994/5) were chosen to be consistent with Srinivasan and Stewart (2004), which is the source of our amenity wage coefficients, $\left(d w / d a_{i}\right)$. These coefficients were estimated using a sample of 12,320 from the 1995 Labour Force Survey, with a standard set of controls for personal characteristics. Among the amenities is an indicator of air quality, denoted by $\mathrm{PM}_{10}$. This measures levels of air-borne particulates that are likely to be inhaled into the lungs (small particles are selected preferentially). Predictions of annual mean levels on a $1 \mathrm{~km}$ grid were generated by 
AEA technology on the basis of $\mathrm{PM}_{10}$ readings from monitoring sites across the UK. These were then converted into county averages using digitalised boundary data.

To test the multimarket amenity model we focus on the prediction that a household that is not part of the labour force has an incentive to locate in a region where amenities are capitalised in the labour market. Individuals above the retirement age were selected as representative of such a group. As noted earlier, the gain from moving from a hypothetical region with zero amenities to region $k$ is given by $-\sum_{i} a_{i k} d w / d a_{i}$. Using data on amenities together with the estimates of $d w / d a_{i}$ referred to above, we calculated, for each county, the amenity wage: $\sum_{i} a_{i k} d w / d a_{i}$.

The test of the model is then whether a negative relationship exists between the presence of retirees in a county (retirees as a proportion of the total population) and the amenity wage. The results of a least squares regression for the 55 counties are presented column (1) of Table 1, where it can be seen that the coefficient on the amenity wage (AMWAGE) is negative and statistically significant at the $1 \%$ level. This constitutes the main result of the paper.

\section{[Table 1 here]}

An alternative test, employed by Graves and Waldman (1991), would be to examine the relationship between migration flows and AMWAGE for retirees and to compare it with that of working age individuals. Unfortunately the age threshold in the migration data is 60 for both women and men, which for the latter does not represent the normal retirement age. Nevertheless, one might consider the age range $15-59$ to be a very rough proxy for individuals in the labour force and the group aged 60 and over as a rough proxy for retirees. We therefore regressed the annual net migration flows of both groups on AMWAGE. The results for the 60 and over age group are shown in columns (2) and (3) of Table 1, and those for 15-59 the group in columns (4) and (5). In each case, one of the specifications incorporates the population level in the destination county (POPULATION) as a control variable. The estimates suggest a clear distinction in the behaviour of the two groups. For the 15-59 age group, the coefficients on AMWAGE are positive but statistically insignificant, whilst for the 60 and over group they are negative and significant. To the extent that the groups represent reasonable proxies for workers and retirees respectively, these findings constitute additional support for the model.

In the light of the above findings, we report, in Table 2, the amenity wage for each county together with their QOL ranking (see equation (5)), given in Srinivasan and Stewart (2004). The amenity wages have been normalised on a hypothetical county with the mean level of each amenity, and the counties are listed in ascending order of this index.

[Table 2 here]

Counties with a low amenity wage tend, not surprisingly, to have a high overall QOL. Generally speaking, counties towards the top of the table enjoy good air quality - in terms of the level of airborne particulates discussed above - but are fairly diverse in other respects. One notable exception to the pattern is Cleveland, which is $10^{\text {th }}$ in 
terms of amenity wage but ranked $45^{\text {th }}$ for QOL. This can be explained, in part, by the fact that Cleveland experiences a high crime rate - an amenity for which compensation occurs in the housing rather than labour market.

\section{Conclusions}

In this paper we have employed Roback's (1982) general equilibrium amenity pricing model to examine the location decisions of retirees in England and Wales. The results strongly support the prediction that retirees will be attracted to counties where amenities are capitalised in the labour market. An analysis of the migration flows of different age groups provides some further support for the model. These findings are consistent with those of Graves and Waldman (1991) and Gabriel and Rosenthal (2004) for the US. From a policy standpoint, the results offer not only a method of predicting the location choices of retirees but also, through investments in amenities, of influencing their decisions. More generally, the results provide support for amenity prices and regional quality of life rankings based on the Roback framework.

\section{Acknowledgements}

We are grateful to AEA Technology and the Climatic Research Unit, University of East Anglia for providing data.

\section{References}

Berger M. C., Blomquist G.C., and Peter K.S. (2008) Compensating differentials in emerging labour and housing markets: estimates of quality of life in Russian cities, Journal of Urban Economics, 63, 25-55.

Blomquist, G.C., Berger, M.C. and Hoehn, J.P. (1988) New estimates of the quality of life in urban areas, American Economic Review, 78, 89-107.

Gabriel S. and Rosenthal S. (2004) Quality of the business environment versus quality of life: do firms and households like the same cities?, The Review of Economics and Statistics, 86, 438-444.

Graves, P.E and Waldman, D.M. (1991) Multimarket amenity compensation and the behaviour of the elderly, American Economic Review, 81, 1374-81.

Gyourko, J. and Tracy, T. (1991) The structure of local public finance and the quality of life, Journal of Political Economy, 99, 774-806.

Roback, J. (1982) Wages, rents, and the quality of life, Journal of Political Economy 90, 1257-1278.

Srinivasan S. and Stewart G. (2004) The quality of life in England and Wales, Oxford Bulletin of Economics and Statistics, 66, 1-23.

\section{Appendix}

[Table A1 here] 
Table 1. Regression results for the proportion of retirees in the population and net migration flows by age group

\begin{tabular}{lccccc}
\hline \multirow{2}{*}{ Variable } & Prop. Retired & \multicolumn{4}{c}{ Net Migration Inflow } \\
\cline { 2 - 5 } & & \multicolumn{2}{c}{ Aged 60 and over } & $(3)$ & Aged 15-59 \\
\hline AMWAGE & $-0.1317^{* *}$ & $-8.7768^{* *}$ & $-7.0577^{* *}$ & 2.8875 & 4.2828 \\
& $(-3.42)$ & $(-2.47)$ & $(-2.44)$ & $(0.70)$ & $(1.12)$ \\
POPULATION & & $-1.1362^{* *}$ & & $-.9222^{* *}$ \\
& & & $(-5.36)$ & & $(-3.29)$ \\
Constant & $1.4615^{* *}$ & $84.6300^{*}$ & $74.6580^{* *}$ & -27.8520 & -35.9503 \\
& $(3.94)$ & $(2.47)$ & $(2.69)$ & $(-0.70)$ & $(-.98)$ \\
RMSE & 0.0241 & 2.0580 & 1.6615 & 0.4890 & 2.2002 \\
F-Stat & 11.73 & 6.10 & 19.07 & 2.06 & 5.69 \\
$\mathrm{R}^{2}$ & 0.18 & 0.10 & 0.43 & 0.01 & 0.18 \\
Observations & 55 & 54 & 54 & 54 & 54 \\
\hline Notes: Explanatory variables are in logs. t-ratios in parentheses. ${ }^{*}$ and ${ }^{* *}$ denote significance at the 5\% and $1 \%$ level respectively \\
(one-tailed for AMWAGE, two-tailed otherwise).
\end{tabular}

Table 2. County rankings by amenity wage and quality of life

\begin{tabular}{lccclccc}
\hline County & $\begin{array}{c}\text { Amwage } \\
\text { rank }\end{array}$ & $\begin{array}{c}\text { Index } \\
\text { Indage }\end{array}$ & $\begin{array}{c}\text { QOL } \\
\text { rank }\end{array}$ & County & $\begin{array}{c}\text { Amwage } \\
\text { rank }\end{array}$ & $\begin{array}{c}\text { Amwage } \\
\text { Index }\end{array}$ & $\begin{array}{c}\text { QOL } \\
\text { rank }\end{array}$ \\
\hline Gwynedd & 1 & -2852 & 3 & Avon & 29 & -164 & 20 \\
Dyfed & 2 & -2268 & 1 & Greater Manchester & 30 & -87 & 21 \\
Cumbria & 3 & -2025 & 4 & W Yorkshire & 31 & -20 & 35 \\
Northumberland & 4 & -1820 & 16 & Dorset & 32 & 143 & 14 \\
Powys & 5 & -1744 & 2 & E Sussex & 33 & 188 & 30 \\
W Glamorgan & 6 & -1653 & 5 & Isle of Wight & 34 & 207 & 29 \\
Mid Glamorgan & 7 & -1512 & 13 & Leicestershire & 35 & 304 & 47 \\
Durham & 8 & -1402 & 18 & Lincolnshire & 36 & 317 & 44 \\
Somerset & 9 & -1104 & 6 & Northamptonshire & 37 & 401 & 38 \\
Cleveland & 10 & -1022 & 45 & Warwickshire & 38 & 565 & 36 \\
Merseyside & 11 & -958 & 22 & Kent & 39 & 652 & 42 \\
Clwyd & 12 & -958 & 11 & Wiltshire & 40 & 666 & 26 \\
Cornwall & 13 & -958 & 12 & W Midlands & 41 & 732 & 28 \\
Nottinghamshire & 14 & -880 & 46 & Oxfordshire & 42 & 938 & 31 \\
Devon & 15 & -853 & 8 & Cambridgeshire & 43 & 940 & 39 \\
Lancashire & 16 & -690 & 9 & Essex & 44 & 1002 & 51 \\
S Glamorgan & 17 & -658 & 7 & Norfolk & 45 & 1087 & 52 \\
Humberside & 18 & -639 & 40 & Hampshire & 46 & 1149 & 37 \\
Hereford and Worcs & 19 & -619 & 10 & Buckinghamshire & 47 & 1207 & 43 \\
Gwent & 20 & -594 & 25 & Bedfordshire & 48 & 1363 & 55 \\
Shropshire & 21 & -509 & 17 & W Sussex & 49 & 1469 & 32 \\
Derbyshire & 22 & -486 & 34 & Hertfordshire & 50 & 1557 & 48 \\
Cheshire & 23 & -476 & 15 & Suffolk & 51 & 1559 & 53 \\
N Yorkshire & 24 & -422 & 19 & Berkshire & 52 & 1604 & 41 \\
Tyne and Wear & 25 & -322 & 24 & Surrey & 53 & 2352 & 49 \\
Staffordshire & 26 & -257 & 33 & Outer London & 54 & 3766 & 54 \\
S Yorkshire & 27 & -238 & 50 & Inner London & 55 & 4229 & 27 \\
Gloucestershire & 28 & -206 & 23 & & & & \\
\hline & & & & & & &
\end{tabular}


Table A1. Variable descriptions and sources

\begin{tabular}{|c|c|c|c|c|}
\hline Variable name & Variable description & Source & Mean & $\begin{array}{r}\text { Wage } \\
\text { coefficient }\end{array}$ \\
\hline Prop. Retired & Proportion of retirees in total population & $\begin{array}{l}\text { Key Population and Vital } \\
\text { Statistics } 1995\end{array}$ & 19.47 & \\
\hline $\begin{array}{l}\text { Net migration inflow aged } \\
60 \text { and over }\end{array}$ & Net annual inflow of people aged 60 and over & $\begin{array}{l}\text { Key Population and Vital } \\
\text { Statistics } 1995\end{array}$ & 0.84 & \\
\hline $\begin{array}{l}\text { Net migration inflow aged } \\
15-59\end{array}$ & Net annual inflow of people aged 15-59 & $\begin{array}{l}\text { Key Population and Vital } \\
\text { Statistics } 1995\end{array}$ & 1.59 & \\
\hline $\mathrm{PM}_{10}$ & Particulates, micrograms per cubic meter & AEA Technology & 17.10 & 486.35 \\
\hline Sunshine & Average annual sunshine hours 1961-90 & $\begin{array}{l}\text { Climatic Research Unit, } \\
\text { UEA }\end{array}$ & 1427 & 2.28 \\
\hline Crime & Notified violent crimes per thousand population & Home Office & 5.15 & -123.14 \\
\hline Unemployment & Claimant unemployment rate (\%) & $\begin{array}{l}\text { Regional Trends 1995, } \\
\text { Employment Gazette } 1995\end{array}$ & 8.44 & -228.35 \\
\hline Pupil-teacher & $\begin{array}{l}\text { Average pupil-teacher ratio in primary and secondary } \\
\text { schools }\end{array}$ & Regional Trends 1996 & 19.72 & 341.07 \\
\hline Nursery & Day nursery places, per 1000 population aged under 5 & Regional Trends 1996 & 38.35 & -11.75 \\
\hline Pop. density & Population density per square $\mathrm{km}$ & $\begin{array}{l}\text { Key Population and Vital } \\
\text { Statistics 1994, Regional } \\
\text { Trends } 1995\end{array}$ & 569.81 & 0.24 \\
\hline London & Dummy variable: 1 if Greater London, 0 elsewhere & Regional Trends 1995 & & 2107.16 \\
\hline AMWAGE & Calculated amenity wage & & 15462 & \\
\hline
\end{tabular}

